\title{
Cellular and humoural autoimmunity markers in Type 2 (non-insulin-dependent) diabetic patients with secondary drug failure
}

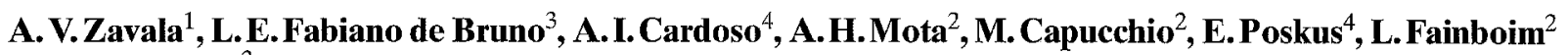 \\ and J.C.Basabe ${ }^{3}$ \\ ${ }^{1}$ Cátedra de Nutrición, ${ }^{2}$ Laboratorio de Inmunogenética, Hospital de Clínicas "General José de San Martín", \\ Universidad de Buenos Aires; ${ }^{3}$ Centro de Investigaciones Endocrinológicas (CEDIE), Hospital General de Niños "Dr. R. Gutierrez"; \\ ${ }^{4}$ Instituto de Estudios de la Inmunidad Humoral (CONICET-UBA), Buenos Aires, Argentina
}

Summary. In some cases patients with Type 2 (non-insulindependent) diabetes mellitus fail to respond to treatment with oral hypoglycaemic agents. These patients may respond in the same way as Type 1 (insulin-dependent) diabetic patients. Cellular immune aggression (defined as the capacity of peripheral mononuclear cells to inhibit stimulated insulin secretion by dispersed rat islet cells), insulin autoantibodies, C-peptide response and HLA antigens were determined in 31 Type 2 diabetic patients with secondary failure to oral hypoglycaemic agents and in 22 control subjects. Nine $(29.03 \%)$ of the 31 Type 2 diabetic patients showed positive cellular immune aggression ( $2 \mathrm{SD}$ below control group) and $22(70.97 \%)$ presented no cellular immune aggression. There was a relationship between positive cellular immune aggression and each of the following parameters: age, body mass index and microangiopathy. No correlation was found be- tween positive cellular immune aggression and glycaemia, $\mathrm{HbA}_{1}$, blood lipids or atherosclerosis. Patients with positive cellular immune aggression showed a significantly lower glucagon-stimulated C-peptide response vs those with no cellular immune aggression. Within a sub-group of patients who had never been treated with insulin, insulin autoantibodies were present in four of six patients with positive cellular immune aggression. DR2 antigen was found with decreased frequency in patients whereas no DR3/DR4 heterozygotes were observed. Our data support the hypothesis that a group of Type 2 diabetic patients with secondary failure to oral hypoglycaemic agents presented autoimmunity towards pancreatic Beta cells.

Key words: Secondary drug failure, C-peptide, anti-Beta-cell autoimmunity, humoural and cellular markers, HLA.
In some cases patients with Type 2 (non-insulin-dependent) diabetes mellitus fail to respond to treatment with oral hypoglycaemic agents (OHA) [1]. Such cases comprise a heterogeneous group of individuals as regards potential physiopathological mechanisms [2].

In certain patients with secondary failure to OHA, a decrease in insulin secretion has been detected [3, 4], as well as islet cell antibodies and certain HLA-DR antigens $[5,6]$. Such patients may have late-onset Type 1 (insulindependent) diabetes since they display a response similar to younger Type 1 diabetic patients [7-9].

However, whether similar genetic, immunological and functional markers indicating an impairment in Beta-cell function are also present in Type 2 subjects with secondary failure to OHA is still an open question. The present report provides information on the effect of peripheral mononuclear cells (MNC) on pancreatic Beta-cell insulin response as a measurement of cellular immune aggression (CIA), on insulin autoantibodies (IAA), on C-peptide response and on HLA antigen in 31 Type 2 patients who failed to respond to treatment with OHA.

\section{Subjects and methods}

\section{Patient population}

Thirty-one Latin American Caucasoid Type 2 diabetic patients who had failed to respond to $\mathrm{OHA}$, comprising 18 males and 13 females, were studied (Group 1). Inclusion criteria were good metabolic control prior to entry by means of diet, physical exercise and OHA treatment for at least 2 years, defined by fasting blood glucose below $7.7 \mathrm{mmol} / \mathrm{l}$ and post-prandial glucose below $11 \mathrm{mmol} / \mathrm{l}$; poor metabolic disease control during the study period even with the maximum OHA doses; and absence of stress, as defined below, on hyperglycaemic drug therapy and fulfilling diet requirements.

Patients presenting with renal, cardiac or hepatic insufficiency, severe ischaemic episodes, lower limb gangrene or cronic infection were excluded from the study.

Mean age \pm SD was $54.77 \pm 12.58$ years (range $30-73$ years) and mean disease duration $9.77 \pm 8.25$ years.

Clinical records for each patient listed: a) usual dietary schedule; b) hypoglycaemic treatment and possible hyperglycaemic drugs; c) absence or presence of stress, due to infection, trauma, vascular accident, or other causes; d) evaluation of nutritional status by body mass index; e) routine laboratory tests including blood count, 
erythrocyte sedimentation rate, urea, uric acid, total cholesterol, triglycerides, HDL cholesterol and LDL cholesterol; f) diabetes control, by glycosuria in 24-h urine collection, pre-breakfast and post-prandial glycaemia, blood and urine glucose self-monitoring, fructosamine and $\mathrm{HbA}_{1} ; \mathrm{g}$ ) evaluation of complications, due to microangiopathy, atherosclerosis, at cardiac or lower limb level; and h) no associated autoimmune disease.

Chinical features and laboratory findings are listed in Table 1.

\section{Control and reference groups}

One group of control subjects and two reference groups were employed:

Group 2: a healthy control group (22 subjects, 12 males and 10 females, age range 24 to 60 years) free of endocrine or autoimmune disease and with no family history of diabetes.

Group 3: Type 2 diabetic reference group (six Type 2 diabetic patients, four male and two female, age range 42 to 58 years) with good response to OHA.

Group 4: Type 1 diabetic reference group (nine children, four male and five female, age range 5 to 16 years) prior to insulin therapy or being treated for up to 3 months, in whom CIA was evaluated for purposes of comparison with the patient population.

Informed consent was given by all subjects in the study. The Ethical Committee of the Hospital de Clínicas and Hospital de Niños, Buenos Aires, Argentina, approved the development of the protocol.

\section{C-peptide dosage}

Beta-cell reserve was measured by C-peptide dosage, as determined by a double antibody technique (Diagnostic Corporation, Los Angeles, Calif., USA) performed in serum collected from patients after an overnight fast and $6 \mathrm{~min}$ after a $1 \mathrm{mg}$ intravenous glucagon injection.

\section{Cellular immune aggression (CIA)}

MNC were processed immediately after blood collection from all subjects, obtaining an MNC-rich preparation from a 15-ml sample by means of Ficoll-Hypaque gradient. Cells were washed twice with Hanks' buffer and suspended in Minimal Essential Medium (MEM; Gibco, Paisley, UK, modified as described below to reach a final $4 \times 10^{6} \mathrm{MNC} / \mathrm{ml}$ concentration.

Islets of Langerhans were obtained from collagenase-treated (Serva, Feinbiochem, Heidelberg, FRG) adult Wistar rat pancreas (CNEA, Buenos Aires, Argentina) by the method of Lacy and Kostianovsky [10]. To obtain islet-cell suspensions, freshly isolated islets were subjected to EDTA and trypsin (Sigma, St. Louis, Mo., USA) as described by Ono et al. [11]. Islet cells were suspended in basal MEM with Eagle salts supplemented with $10 \%$ fetal calf serum, $2 \mathrm{mmol} / \mathrm{l}$ glutamine, $1 \mathrm{mmol} / \mathrm{l}$ sodium pyruvate, $0.814 \mathrm{mg} / 1$ non-essential amino acids (Gibco) and $100 \mu U$ penicillin.

Cell viability was estimated by the trypan blue exclusion test and only suspensions having at least $90 \%$ viable cells were employed.

Islet-cell stimulation [12] was performed as follows. The isletcell suspension was placed in 96-well Falcon microtest plates (Becton Dickinson, Oxnard, Calif., USA) $5 \times 10^{3}$ cells per well with the addition of MNC from either control subjects or diabetic patients MNC $\left(4 \times 10^{6}\right.$ cells perwell in $\left.100 \mu \mathrm{l}\right)$ or basal medium $(100 \mu \mathrm{l})$ and incubated for $18 \mathrm{~h}$ (ten wells for each diabetic patient or control subject MNC preparation). At the end of this incubation, wells were carefully washed and the supernatant collected to assess prestimulatory insulin release. Medium was replaced by $200 \mu \mathrm{l}$ basal medium (glucose $5.5 \mathrm{mmol} / \mathrm{l}$ ) or $200 \mu \mathrm{l} \mathrm{stimulatory} \mathrm{medium} \mathrm{(glu-}$ cose $16.5 \mathrm{mmol} / \mathrm{l}$ and theophylline $5 \mathrm{mmol} / \mathrm{l}$ ); five wells for each
Table 1. Clinical features and laboratory data of 31 Type 2 (non-insulin-dependent) diabetic patients

\begin{tabular}{|c|c|c|c|c|c|c|}
\hline $\begin{array}{l}\text { Patient } \\
\text { number }\end{array}$ & $\begin{array}{l}\text { Age/Sex } \\
\text { (years) }\end{array}$ & $\begin{array}{l}\text { Age of } \\
\text { onset } \\
\text { (years) }\end{array}$ & $\begin{array}{l}\mathrm{BMI} \\
\left(\mathrm{kg} / \mathrm{m}^{2}\right)\end{array}$ & $\begin{array}{l}\text { C-peptide } \\
\text { (nmol/l) }\end{array}$ & $\mathrm{ClA}^{c}$ & $\begin{array}{l}\text { IAA-IA }^{d} \\
(\%)\end{array}$ \\
\hline 1 & $72 \mathrm{M}$ & 50 & 20.8 & 0.05 & 20.00 & 102 \\
\hline 2 & $39 \mathrm{M}$ & 19 & 18.5 & 0.05 & 22.60 & 67 \\
\hline $3^{a}$ & $33 \mathrm{M}$ & 19 & 22.5 & 0.54 & 23.60 & 76 \\
\hline 4 & $66 \mathrm{M}$ & 50 & 23.7 & & 26.12 & neg \\
\hline $5^{a}$ & $36 \mathrm{M}$ & 33 & 24.6 & 0.54 & 20.05 & 17 \\
\hline $6^{a}$ & $30 \mathrm{M}$ & 27 & 20.2 & 0.04 & 23.53 & neg \\
\hline $7^{a}$ & $65 \mathrm{~F}$ & 62 & 21.2 & 0.60 & 21.35 & 40 \\
\hline $8^{a}$ & $42 \mathrm{~F}$ & 39 & 21.5 & 0.11 & 22.85 & 27 \\
\hline 9 & $48 \mathrm{~F}$ & 45 & 27.0 & & 24.09 & neg \\
\hline $10^{\mathrm{a}}$ & $56 \mathrm{M}$ & 54 & 22.5 & & 26.93 & 28 \\
\hline $11^{\mathrm{a}}$ & $64 \mathrm{M}$ & 52 & 25.4 & & 27.43 & neg \\
\hline $12^{\mathrm{a}}$ & $60 \mathrm{~F}$ & 56 & 28.7 & 1.58 & 27.57 & neg \\
\hline 13 & $42 \mathrm{~F}$ & 29 & 22.5 & 0.11 & 27.89 & neg \\
\hline 14 & $67 \mathrm{~F}$ & 56 & 23.8 & & 27.61 & neg \\
\hline 15 & $68 \mathrm{~F}$ & 48 & 20.5 & 0.40 & 27.29 & neg \\
\hline 16 & $43 F$ & 40 & 21.3 & & 27.96 & neg \\
\hline 17 & $64 \mathrm{~F}$ & 54 & 27.4 & 0.21 & 30.76 & 1 \\
\hline 18 & $58 \mathrm{~F}$ & 56 & 19.9 & & 29.62 & neg \\
\hline 19 & $68 \mathrm{~F}$ & 58 & 20.0 & 0.67 & 29.27 & neg \\
\hline 20 & $56 \mathrm{~F}$ & 41 & 33.3 & 0.21 & 31.17 & neg \\
\hline 21 & $64 \mathrm{M}$ & 24 & 20.8 & 0.70 & 28.34 & neg \\
\hline $22^{a}$ & $41 \mathrm{~F}$ & 39 & 20.5 & 0.20 & 28.55 & 50 \\
\hline 23 & $73 \mathrm{M}$ & 65 & 20.2 & & 28.96 & neg \\
\hline $24^{a}$ & $34 \mathrm{M}$ & 32 & 29.8 & & 28.76 & neg \\
\hline 25 & $68 \mathrm{M}$ & 64 & 28.4 & 0.30 & 30.20 & neg \\
\hline $26^{a}$ & $62 \mathrm{M}$ & 50 & 21.3 & 0.18 & 28.12 & 33 \\
\hline 27 & $52 \mathrm{M}$ & 41 & 23.5 & 0.40 & 28.79 & neg \\
\hline 28 & $55 \mathrm{M}$ & 43 & 21.2 & 0.96 & 29.07 & neg \\
\hline 29 & $54 \mathrm{M}$ & 50 & 23.5 & 0.52 & 30.13 & neg \\
\hline 30 & $60 \mathrm{M}$ & 46 & 26.7 & 0.08 & 29.55 & neg \\
\hline 31 & $58 \mathrm{M}$ & 53 & 24.1 & 0.04 & 28.97 & neg \\
\hline
\end{tabular}

${ }^{a}$ Patients were treated at least once with insulin.

Value obtained $6 \mathrm{~min}$ after glucagon stimulus. Normal values: $>0.7 \mathrm{nmol} / \mathrm{l}$.

${ }^{\circ}$ CIA, Cellular immune aggression. Control values $29.63 \pm 3.06$. Insulin $\mu \mathrm{U} \cdot 5000$ cells $^{-1} \cdot 5 \mathrm{~min}^{-1}($ mean $\pm 2 \mathrm{SD}, n=22)$.

${ }^{d}$ IAA-IA, Insulin autoantibody-insulin antibody level. 100\% and $0 \%$ values defined as indicated in Subjects and methods.

$\mathrm{M}$, male; $\mathrm{F}$, female; neg, negative

basal or stimulatory medium were employed. MNC remained with islet cells during both basal and stimulatory periods. Supernatants were withdrawn after $5 \mathrm{~min}$ and rapidly frozen for insulin determination.

Insulin was determined by radioimmunoassay [13] using purified rat insulin as standard (Novo Nordisk, Gentofte, Denmark), porcine ${ }^{125} \mathrm{I}$-insulin as tracer (CNEA) and guinea pig anti-porcine insulin antiserum.

Insulin assay sensitivity was $0.5 \mu \mathrm{U} / \mathrm{i}$; intra-assay coefficient of variation (CV) was $8.7 \%, 6.2 \%$ and $5.1 \%$ for $1-5,5-10$ and 10 $50 \mu \mathrm{U}$ insulin/ml determination ranges, respectively; inter-assay $\mathrm{CV}$ was $6.57 \%, 4.96 \%$ and $5.18 \%$ for the given ranges, respectively.

Islet-cell function is expressed as the net insulin secretion ( $\mu \mathrm{U}$ per 5000 cells) during 5 -min incubation in the presence of basal or stimulatory medium $\left(\mu \mathrm{U} \cdot 5000\right.$ cells $\left.^{-1} .5 \mathrm{~min}^{-1}\right)$.

Net basal secretion is given for the same 5-min period in basal medium minus pre-stimulatory secretion, while net stimulated secretion is also given for the same $5-\mathrm{min}$ period in stimulatory medium minus the pre-stimulatory secretion.

Results of CIA test (net stimulated secretion) were reproducible with a $3.93 \%$ inter-assay and a $4.15 \%$ intra-assay CV, both for control subjects and patients. 
Table 2. Insulin secretion in the presence of mononuclear cells from control, reference and patient groups with Type 1 (insulin-dependent) and Type 2 (non-insulin-dependent) diabetes mellitus

\begin{tabular}{|c|c|c|c|}
\hline Group & $\begin{array}{l}\text { Pre-stimulatory secretion } \\
\text { (mean } \pm \text { SD) }\end{array}$ & $\begin{array}{l}\text { Net basal secretion } \\
(\text { mean } \pm \mathrm{SD})\end{array}$ & $\begin{array}{l}\text { Net stimulated secretion } \\
(\text { mean } \pm \text { SD) }\end{array}$ \\
\hline $\begin{array}{l}\text { 1.A. CIA-negative Type } 2 \text { diabetic patients with } \\
\text { secondary failure to OHA. (Group } 1 \mathrm{~A}, \text { Fig. } 1 ; n=22 \text { ) }\end{array}$ & $2.20 \pm 0.05$ & $4.89 \pm 0.75$ & $28.77 \pm 1.23$ \\
\hline $\begin{array}{l}\text { 1.B. CIA-positive Type } 2 \text { diabetic patients with } \\
\text { secondary failure to OHA. (Group } 1 \text { B, Fig. } 1 ; n=9 \text { ) }\end{array}$ & $2.31 \pm 0.11$ & $5.19 \pm 1.03$ & $22.89 \pm 2.25^{\mathrm{a}}$ \\
\hline 2. Healthy control subjects $(n=22)$ & $2.23 \pm 0.10$ & $5.01 \pm 1.10$ & $29.63 \pm 1.53$ \\
\hline $\begin{array}{l}\text { 4. Newly diagnosed Type } 1 \text { diabetic patients } \\
\text { (Group } 4 \text {, Fig. } 1 ; n=9 \text { ) }\end{array}$ & $2.35 \pm 0.12$ & $5.53 \pm 1.16$ & $17.94 \pm 3.19^{\mathrm{a}}$ \\
\hline
\end{tabular}

Results are expressed as $\mu \mathrm{U}$ insulin $\cdot 5000$ cells $^{-1} \cdot 5 \mathrm{~min}^{-1}$.

${ }^{a} p<0.01$ vs healthy control group. Other comparisons were not statistically significant except for Group 1.A vs Group 1.B ( $\left.p<0.05\right)$.

CIA, Cellular immune aggression

\section{Insulin antibody $(I A)$ and insulin autoantibody (IAA) determination}

Blood samples were collected after an overnight fast and sera stored at $-20^{\circ} \mathrm{C}$ until assayed. Mono ${ }^{125} \mathrm{I}$-(A14)-human insulin was prepared from Humulin R (Eli Lilly, Indianapolis, Ind., USA) and chromatographed through Sephadex G-25 (Pharmacia, Uppsala, Sweden) to avoid the interference of preservative substances. Labelling and purification procedures were as described by Linde et al. [14].

Specific radioactivity of $300 \mu \mathrm{Ci} / \mu \mathrm{g}$ was routinely achieved. Corrections according to tracer stability [15] were introduced for tracer fractions stored at $-20^{\circ} \mathrm{C}$ in order to minimize inter-assay $\mathrm{CV}$. Radiobinding assays were performed essentially as described by Palmer et al. [16]. Two appropriate dilutions of guinea pig anti-insulin hyperimmune serum were used in each assay as positive control (low and high standards). The mean binding value of the high standard was arbitrarily taken as $100 \%$. Non-specific binding was defined as tracer binding to sera from non-diabetic subjects (mean $+3 \mathrm{SD}$; $n=30$ ). Results from unknown sera were corrected by subtracting non-specific binding.

Intra-assay CV was $4.87 \%$ and $15.89 \%$ for high and low standards, respectively $(n=30)$, while corresponding values for interassay CV were $4.87 \%$ and $14.80 \%$, respectively $(n=12)$.

IA and IAA were scored as positive when bound tracer percentage exceeded the mean $+3 \mathrm{SD}$ of sera from healthy control subjects analysed during the same assay.

\section{Lymphocyte isolation and typing}

Blood samples were collected from 25 patients and 144 normal control subjects, all belonging to a homogeneous Argentinian population of Latin American Caucasoids. HLA were typed using the same set of sera.

Lymphocytes were isolated from peripheral blood by density gradient centrifugation on Ficoll-Hypaque. HLA A, B and C antigens were determined using the two-stage microlymphocyte-cytotoxicity assay $[17]$.

HLA DR and DQ antigen typing was performed by the two-colour fluorescence test [18]. Sera from the Fifth Latin American Histocompatibility Workshop were used, as well as local sera and sera obtained by exchange with international laboratories.

\section{Statistical analysis}

Data were processed by the two-tailed Student's $t$-test for unpaired samples and by the one-way ANOVA and Scheffe's test [19].

\section{Results}

\section{Cellular immune aggression (CIA)}

In the presence of control MNC, net basal and net stimulated insulin release were $5.01 \pm 1.10$ and $29.63 \pm 1.53 \mu \mathrm{U}$ insulin $\cdot$ cells $^{-1} \cdot 5 \mathrm{~min}^{-1}$, respectively (Table 2 ). Net basal and net stimulated insulin secretion in the presence of

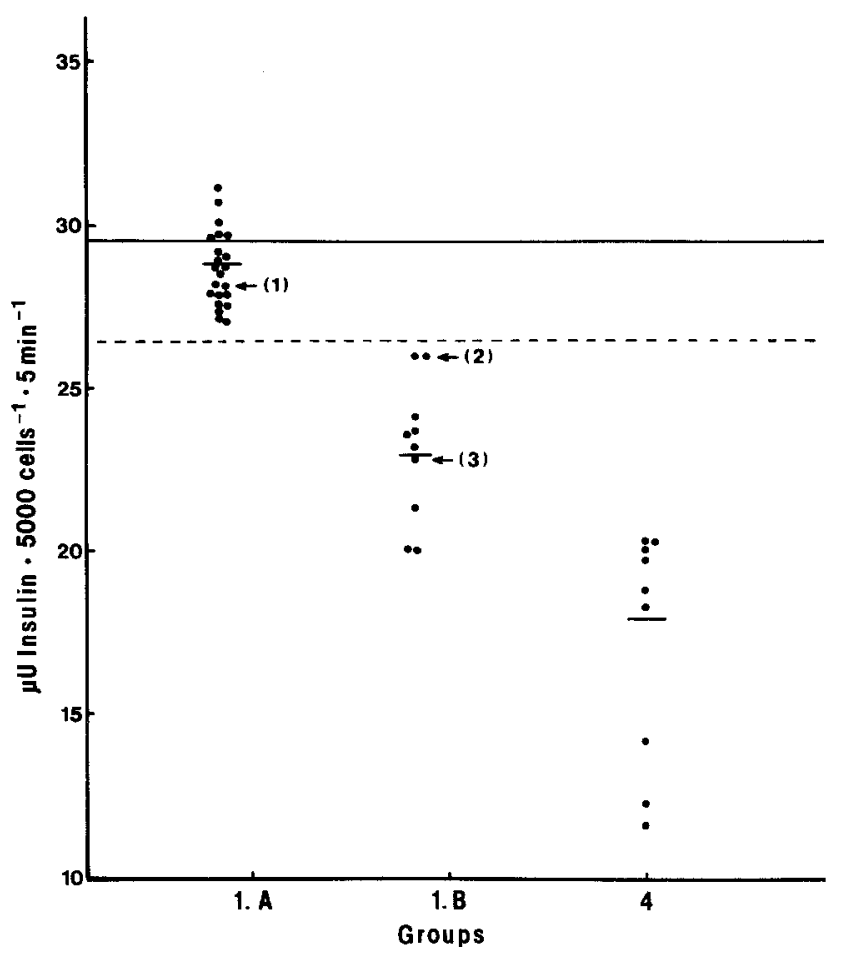

Fig. 1. Insulin secreted by dispersed rat islet cell suspension in the presence of mononuclear cells from 31 Type 2 (non-insulin-dependent) diabetic patients with secondary failure to oral hypoglycaemic agents. Group 1.A, 22 patients without inhibition of insulin secretion; Group 1.B, 9 patients with values below 2 SD; and Group 4, 9 newly-diagnosed Type 1 (insulin-dependent) diabetic patients. Each point represents the mean of five determinations. (1), (2) and (3) correspond to three consecutive blood samples collected from patient 2 . Mean and mean -2 SD values belong to the healthy control group $(n=22)$. Mean value $(-)$; dotted line $(\cdots), 2$ SD 
Table 3. Frequency of HLA DR and DQ antigens in Type 2 (noninsulin-dependent) diabetic patients with secondary failure to oral hypoglycaemic agents vs normal control subjects

\begin{tabular}{llrlll}
\hline HLA & $\begin{array}{l}\text { Normal control } \\
\text { subjects } \\
n=144(\%)\end{array}$ & $\begin{array}{l}\text { Diabetic } \\
\text { patients } \\
n=25(\%)\end{array}$ & $\begin{array}{l}\text { chi- } \\
\text { square }\end{array}$ & $p$ value & $\begin{array}{l}\text { Relative } \\
\text { risk }\end{array}$ \\
\hline DR1 & $26(18.0)$ & $7(28.0)$ & NS & & \\
DR2 & $33(23.0)$ & $1(4.0)$ & 4.74 & $<0.05$ & 0.14 \\
DR3 & $21(14.6)$ & $4(16.0)$ & NS & & \\
DR4 & $43(30.0)$ & $3(12.0)$ & NS & & \\
DR5 & $42(29.2)$ & $4(16.0)$ & NS & & \\
DR6 & $23(16.0)$ & $5(20.0)$ & NS & & \\
DR7 & $37(25.7)$ & $10(40.0)$ & NS & & \\
DR8 & $15(10.4)$ & $2(8.0)$ & NS & & \\
DR9 & $8(5.6)$ & $0(0)$ & NS & & \\
DRw10 & $3(2.1)$ & $0 \quad(0)$ & NS & & \\
DQw1 & $76(52.8)$ & $13(52.0)$ & NS & & \\
DQw2 & $58(40.3)$ & $11(44.0)$ & NS & & \\
DQw3 & $94(65.3)$ & $10(40.0)$ & NS & & \\
\hline
\end{tabular}

NS, Not significant $(p>0.05)$

MNC from Type 2 diabetic control patients (Group 3) without secondary failure to OHA were not significantly different from healthy control subjects.

The 31 diabetic patients with secondary failure to OHA were divided into two groups (Fig. 1 and Table 2):

Group 1.A, 22 patients ( $70.97 \%$ ) with no inhibition of stimulated insulin secretion (Fig. 1, Table 2); and

Group 1.B, 9 patients $(29.03 \%)$ presenting values at least $2 \mathrm{SD}$ below control levels, regarded as CIA-positive (Fig. 1, Table 2).

In the presence of $\mathrm{MNC}$ from the Type 1 diabetic patient reference group (Group 4) (Fig. 1; Table 2), the amount of insulin secreted remained 2 SD below control values (CIA-positive).

\section{CIA in relation to biological variables}

Sex: there were no significant inter-group differences.

Age: mean age of CIA-positive patients was $47.88 \pm 15.60$ years vs $57.80 \pm 10.10$ years in CIA-negative patients $(p<0.01)$.

Duration of diabetes: in CIA-positive patients mean disease duration was $9.60 \pm 8.21$ years vs $12.12 \pm 9.03$ years in CIA-negative patients.

BMI: patients with positive CIA had lower BMI (21.72 \pm $1.84 \mathrm{~kg} / \mathrm{m}^{2} ; p<0.05$ ) when compared to group 1.A.

Glycaemia, $\mathrm{HbA}_{I}$ and blood lipids: there were no significant differences in CIA-positive and negative subjects.

\section{CIA in relation to diabetic complications}

The study showed that CIA-negative patients had more complications vs CIA-positive patients $(59.83 \%$ vs $36.36 \% ; p<0.05)$. When complications were divided into two groups, atherosclerotic and microangiopathic, it was found that CIA-negative diabetic patients were more prone to atherosclerotic complications, whereas CIApositive patients had more microangiopathic complications, similar to those observed in Type 1 diabetes.

\section{CIA in relation to pancreatic Beta-cell reserve}

Table 1 includes C-peptide values obtained from serum samples. C-peptide responses to glucagon proved significantly different in CIA-positive vs negative patients $(0.21 \pm 0.24$ vs $0.45 \pm 0.25 \mathrm{mmol} / 1, p<0.05$, respectively $)$.

\section{Insulin antibody-insulin autoantibody levels (IA-IAA)}

Ten of the 31 patients ( $32 \%$ ) exhibited binding exceeding the conventional positivity limit (presence of IAA or IA, or both), but only three corresponded to patients with no prior insulin injection (presence of IAA); although sera from patients numbers 3 and 8 strictly belonged to the subgroup of patients treated at least once with insulin, they showed a relatively high level of specific antibodies (Table 1). Given the brief therapy period (20 and 3 days, respectively), significant IA levels were considered unlikely. Therefore, we tentatively placed these two serum samples together with the group of three sera from patients with no previous insulin treatment (presence of IAA). None of the Type 2 diabetic control patients exhibited binding exceeding the conventional positivity limit.

Potential IAA-CIA correlation was tested: firstly, regarding the IAA-positive patients as a single group; although IAA levels were assayed in all 31 patients (Table 1), 22 (including patients 3 and 8 as stated above) had no prior insulin treatment. In this subgroup, 4 of 22 were IAA- and CIA-positive; one was IAA-positive and CIA-negative; 2 were IAA-negative and CIA-positive; and the remaining 15 proved negative to both tests. Secondly, regarding IAA positivity within the group of CIApositive patients: 6 of 9 (Fig. 1, Group 1.B) had no prior insulin treatment; 4 were IAA- and CIA-positive; and 2 were IAA-negative and CIA-positive. Patient 2, initially IAA-positive and CIA-negative (Fig. 1, sample 1), showed both IAA and CIA positivity in two consecutive determinations carried out in samples obtained 10 and 18 months after the initial sample was taken (Fig. 1, samples 2 and 3 , respectively).

\section{HLA antigen typing}

Comparing the frequency of HLA A, B and C loci in diabetic patients with those of normal control subjects, only HLA-B7 was found to be decreased $(4.0 \%$ in patients vs $12.0 \%$ in normal control subjects), but the difference failed to reach statistical significance.

HLA class II antigen frequency is shown in Table 3. At the DR locus, HLA-DR7 occurred more frequently in patients vs normal control subjects, but again the difference was non-significant. 
HLA-DR2 antigen was observed in a single patient (number 22) of the 25 studied ( $4.0 \%$ in patients vs $23.0 \%$ in normal control subjects); relative risk (RR) was 0.14 , with chi square $=4.74$ and $p<0.05$.

Interestingly, none of the 25 patients presented the DR3/DR4 phenotype described as occurring in $52 \%$ of Type 1 diabetic patients $(n=17)$ belonging to the same ethnic group [20].

\section{Discussion}

We have attempted to determine whether an immune mechanism, involving the presence of immune markers, such as CIA and IAA, as well as HLA antigens and residual C-peptide Beta-cell function operates in Type 2 patients with secondary failure to OHA.

Data from our present CIA studies suggest that almost one-third $(29.03 \%)$ of Type 2 diabetic patients unresponsive to OHA are prone to develop immune aggression towards pancreatic Beta cells. Furthermore, the newly-diagnosed Type 1 diabetic patients also exhibited CIA without exception. Together with other immunological and metabolic parameters, CIA has already been used to identify individuals at high risk of developing overt Type 1 diabetes, as well as to evaluate "diabetic" MNC transfer and Beta-cell function [21,22]. Boitard et al. [23] have shown that MNC inhibition of insulin secretion is affected by lymphocytes bearing the $\mathrm{CD} 3+, \mathrm{CD} 4-, \mathrm{CD} 8+$ phenotype, although the role of other T-cell subpopulations and stimulatory-inhibitory effects of cytokines on the Beta cell $[24,25]$ cannot be ruled out.

Inhibitory MNC effect, as shown by CIA study, appears specific to pancreatic Beta cells since no cytotoxicity is observed against mouse fibroblast and glucagon secretion remains unchanged during the test $[12,23]$. Splenocytes from mice rendered diabetic by multiple low-dose streptozotocin treatment were found to inhibit stimulated insulin secretion from dispersed rat islet cells, but had no effect on somatostatin secretion [L. Fabiano de Bruno, unpublished observations]. Such insulin secretion inhibition is unaffected by insulin treatment, the presence of antibody, complement or aggregated $\operatorname{IgG}[12$, $21,26]$.

Binding of $\mathrm{MNC}$ from patients with recent-onset Type 1 diabetes to RIN cells or islets, not observed in nondiabetic patients with other progressive organ-specific autoimmune diseases, has been reported [27]. Also, cytoadherence of "diabetic" lymphocytes increased in a highly correlated fashion in two xenogeneic species, namely rat and hamster, but failed to do so in seven noninsulin secreting cell-lines $[24,27,28]$.

Four of six of the patients with positive CIA with no previous insulin treatment also showed the presence of IAA, further indicating that autoimmune aggression is a contributory factor leading to secondary failure to OHA. However, it is noteworthy that 10 out of 31 positive IAAIA samples included at least five sera with well-established positive IAA, whereas in the remainder the possible presence of IA induced by exogenous insulin obscured IAA marker detection.
Measurement of glucagon-stimulated C-peptide levels provides reliable information on pancreatic Beta-cell reserve [29]. The relationship between CIA and decline in Beta-cell function again stresses the role of autoimmunity in the pathogenesis of Type 2 diabetes with secondary failure to OHA.

The presence of low C-peptide and of islet-cell antibodies in adult-onset diabetes has also been regarded as marker for latent autoimmune or Type 1 diabetes, as such patients commonly require insulin therapy at a later stage $[5,8]$.

On the whole, our present results are in agreement with previous observations by Groop et al. [7] based on the determination of islet and thyrogastric antibodies from Type 2 diabetic patients requiring insulin therapy.

Should the patients in our study actually be late-onset Type 1 diabetic patients, they would be expected to exhibit the characteristic HLA DR3/DR4 antigens [20,30]. In this regard, Groop et al. [31] described greater DR4 frequency and a trend to increased heterozygous DR3/DR4 frequency in Type 2 diabetic patients requiring insulin therapy. However, here we found no evidence of such an HLA association and HLA-DR2 antigen frequency was lowered in our series. Given the involvement of diverse HLA class II antigens in our Type 2 diabetic patient population with secondary failure to OHA, it may be speculated that genes coding for these antigens, or susceptibility antigen-linked gene(s), differ according to the respective ethnic group.

Autoimmune responses display cellular and humoural components acting in a concerted manner. Our data indicate that both components seem to be at work in this patient population. Hence, detection of markers depicting the ongoing autoimmune process and accurate evaluation of residual Beta-cell function are useful steps before further immunomodulatory therapy can be contemplated.

To conclude, CIA, IAA and glucagon-stimulated Cpeptide screening, regarded as markers in Type 1 diabetes, also appear to be valuable tools in Type 2 diabetes.

Acknowledgements. The authors wish to thank Drs. E. Osinde and H. Mainetti for their contribution of immunoanalysis to this study. This work was supported by grants from the Consejo Nacional de Investigaciones Científicas y Técnicas, the Universidad de Buenos Aires, Fundación A. J. Roemmers and Fondo Cruz del Sur, Argentina.

\section{References}

1. Krall L, Bradley M (1962) Secondary failure in the treatment of diabetes mellitus with tolbutamide and with phenformine. Diabetes 11 [Suppl]: 88A (Abstract)

2. Mehnert $H$ (1962) Clinical and experimental finding after five years treatment of diabetes with sulfonylureas. Diabetes 11 [Suppl]: 80A (Abstract)

3. Himsworth H (1986) Diabetes mellitus: a differentiation into insulin sensitive and insulin-insensitive types. Lancet I: 127-128

4. Liu C, Coulston A, Reaven G (1983) Does day long absolute hypoinsulinemia characterize the patients with non-insulin dependent diabetes mellitus? Metabolism 32: 754-756 
5. Gleichmann H, Zorcher B, Grenlich B et al. (1984) Correlation of islet cell antibodies and HLA-DR phenotypes with diabetes mellitus in adults. Diabetologia 27: 90-92

6. Landin-Olsson M, Nilsson KO, Lernmark $\AA$, Sundkvist G (1990) Islet cell antibodies and fasting C-peptide predict insulin requirement at diagnosis of diabetes mellitus. Diabetologia 33: 561-568

7. Groop L, Bottazzo G, Doniach D (1986) Islet cell antibodies identify latent type I diabetes in patients aged $35-75$ at diagnosis. Diabetes 35: 237-241

8. Groop L, Pelkonen R, Roakimiej S, Bottazzo G, Doniach D (1986) Secondary failure treatment with oral antidiabetic agents in non-insulin-dependent diabetes. Diabetes Care 9: 129-132

9. Madsbad S, Krarup T, Christensen C (1981) Practical clinical value of the $\mathrm{C}$-peptide response to glucagon stimulation in the choice of treatment in diabetes mellitus. Acta Med Scan 210: 153-155

10. Lacy PE, Kostianovsky M (1967) Method for the isolation of intact islets of Langerhans from the rat pancreas. Diabetes 16: 3539

11. Ono J, Takaki R, Fukuma M (1977) Preparation of single cells from pancreatic islets, of adult rats by the use of dispase. Endocrinology Jpn 24:265-270

12. Boitard C, Debray-Sachs M, Plouplard A, Assan R, Hamburger $\mathrm{J}$ (1981) Lymphocytes from diabetics suppress insulin release in vitro. Diabetologia 21: 41-46

13. Herbert V, Lau K, Gottlieb C, Bleicher SJ (1965) Coated charcoal immunoassay of insulin. J Clin Endocr Metab 25:1375-1384

14. Linde S, Hansen B, Lernmark $\AA$ (1983) Preparation of stable radioiodinated polypeptide hormones and proteins using polyacrylamide gel electrophoresis. In: Langone JJ, Van Vunakis H (eds) Methods in enzymology, Vol 92. Academic Press, Orlando San Diego New York Austin London Montreal Sydney Tokyo Toronto, pp 305-309

15. Linde S, Hansen B, Sonne O, Holst JJ, Gliemann J (1981) Tyrosine A14 $\left[{ }^{125} \mathrm{I}\right]$ monoiodoinsulin. Preparation, biologic properties and long-term stability. Diabetes 30:1-8

16. Palmer JP, Asplin CM, Clemons P et al. (1983) Insulin antibodies in insulin-dependent diabetics before insulin treatment. Science 222: 1337-1339

17. Terasaki PI, McClelland JD (1964) Microdroplet assay of human serum cytotoxins. Nature 204: 998-1000

18. Van Road JJ, Van Heeusen A, Pleon JS (1976) Simultaneous detection of two cell population by two-colour fluorescence and its application to the recognition of beta-cell determinants. Nature 262: 295-297

19. Rattcliffe JT (1969) Elements of mathematical statistics. Oxford University Press, London

20. Ruiz M, Puchulu F, Christensen A (1988) Genetic and humoral markers in IDDM patients and their families. In: Camerini-Davalos RA, Cole HS (eds) Advances in experimental medicine and biology: prediabetes, Vol 246. Plenum Press, New York London, pp 241-247
21. Basabe JC (1989) The immune system and islet function. In: Larkins R, Zimmet P, Chisholm D (eds) Diabetes 1988. Elsevier Science Publishers, Amsterdam, pp 37-44

22. Basabe JC, Fabiano de Bruno LE, Arata M (1988) Diabetic lymphocytes transfer and beta cell function. In: Camerini-Davalos RA, Cole HS (eds) Advances in experimental medicine and biology: prediabetes, Vol 246. Plenum Press, New York London, pp 101-108

23. Boitard C, Chatenaud LM, Debray-Sachs M (1982) In vitro inhibition of pancreatic beta-cell function by lymphocytes from diabetics with associated autoimmune disease: a T-cell phenomenon. J Immunol 129: 2529-2531

24. Wogensen L, Reimers J, Mandrup-Poulsen T, Nerup J (1991) Repeated intraperitoneal injections of interleukin $1 \beta$ induce glucose intolerance in normal rats. Acta Endocrinol (Copenh) 124: $470-478$

25. Mandrup-Poulsen T, Helquist S, Molvig J, Wogensen L, Nerup J (1989) Cytokines as immune effector molecules in autoimmune diseases with special reference to insulin dependent diabetes mellitus. Autoimmunity 4: 191-218

26. Boitard C, Sai P, Debray-Sachs M, Assan R, Hamburger J (1984) Antipancreatic immunity: "in vitro" studies of cellular and humoral immune reactions directed toward pancreatic islet. Clin Exp Immunol 55: 571-580

27. Lang F, Maugendre D, Houssaint E, Charbonnel B, Sai P (1987) Cytoadherence of lymphocytes from type 1 diabetic subjects to insulin-secreting cells; marker of anti beta-cell cellular immunity. Diabetes 36: 1356-1364

28. Segain J, Valentin A, Bardet S et al. (1989) In vitro relationship of CD4 cells from type I diabetic patients and xenogenic betacell membranes. Diabetes 38: 634-640

29. Binder C, Faber O (1978) Residual $\beta$-cell function in children with diabetes. C-Peptide levels gives reliable information about the beta-cell reserve. Diabetes 27:226-229

30. Wolf E, Spencer KM, Cudworth AG (1983) The genetic susceptibility to type 1 (insulin-dependent) diabetes: analysis of the HLA-DR association. Diabetologia 24: 224-230

31. Groop L, Miettinen A, Groop P-H, Meri S, Koskimies S, Bottazzo GF (1988) Organ-specific autoimmunity and HLA-DR antigens as markers for beta-cell destruction in patients with type II diabetes. Diabetes 37: 99-103

Received: 27 November 1991

and in final revised form: 17 August 1992

Dr. A. V.Zavala

Cátedra de Nutrición

Hospital de Clínicas (UBA)

Av. Córdoba 2351

(1120) Buenos Aires

Argentina 